\title{
Use of the AppsGeyser application in the assessment of self- study activities in English for the equality education
}

\author{
Nining Setyowati a,1,* \\ ${ }^{a}$ SMK YP 17 BLITAR and PKBM ILMU BAROKAH, JI. Maluku No. 14, Kota Blitar, East Java 66137, Indonesia \\ 1ni3nkstw@gmail.com \\ * Corresponding author
}

\begin{tabular}{|c|c|}
\hline ARTICLE INFO & ABSTRACT \\
\hline $\begin{array}{l}\text { Article history } \\
\text { Received: 2020-06-28 } \\
\text { Revised: 2020-07-21 } \\
\text { Accepted: 2020-12-15 } \\
\text { Published: 2020-12-29 } \\
\text { Keywords } \\
\text { AppsGeyser application } \\
\text { Assessment } \\
\text { Package C } \\
\text { Self-study }\end{array}$ & $\begin{array}{l}\text { Learning English as a subject that is taught independently to citizens learning non-formal education } \\
\text { is one of the most important things to face the challenges of the future and global life, as targeted } \\
\text { in SDGs-goal } 4 \text {. One of the innovative learning strategies that support learning English independently } \\
\text { is the use of internet applications. AppsGeyser application is an internet application that allows users } \\
\text { to use it offline. With this application we can easily distribute content from websites, blogs and } \\
\text { certain files that we want to share via the Android application. The use of android in the process of } \\
\text { learning English activities independently. The purpose of writing this real work is to describe and } \\
\text { explain the use of the AppsGeyser application in self-study activities in the English language } \\
\text { equivalency education package C. The method used in this real work is quantitative descriptive. The } \\
\text { population used was all citizens learning the chasing equivalence education package C in PKBM Ilmu } \\
\text { Barokah, totaling } 10 \text { citizens learning from grade } 3 \text {. The instruments used in obtaining data were in } \\
\text { the form of pretest and posttest with percentage data analysis techniques. The results achieved by } \\
\text { learning citizens after using the AppsGeyser application as a learning medium, namely learning } \\
\text { citizens become easier to do, enthusiastic in doing quizzes, easier to remember material so that they } \\
\text { can answer quizzes smoothly, are more independent in studying learning materials and the results } \\
\text { of evaluation of learning citizens increase compared to before using the app. } \\
\text { This is an open access article under the CC-BY-SA license }\end{array}$ \\
\hline
\end{tabular}

How to cite: Setyowati, N. (2020). Use of the AppsGeyser application in the assessment of self-study activities in English for the equality education. Journal of Community Service and Empowerment, 1(3), 142-149. https://doi.org/10.22219/jcse.v1i3.12698

\section{PENDAHULUAN}

Pendidikan sebagai proses transformasi budaya sejatinya menjadi wahana bagi perubahan dan dinamika kebudayaan masyarakat dan bangsa (Chakraborty et al., 2018; Gartman, 2002; Pruneri \& Bianchi, 2010). Pendidikan yang diberikan melalui bimbingan, pengajaran, dan latihan harus mampu memenuhi tuntutan pengembangan potensi peserta didik secara maksimal, baik potensi intelektual, spiritual, sosial, moral, maupun estetika sehingga terbentuk kedewasaan atau kepribadian seutuhnya (Gusnimar \& Siahaan, 2018; Pratiwi, 2018; Sandi, 2018; Sarima et al., 2020; Tusyana, 2019). Pendidikan dapat diperoleh melalui pendidikan formal dan non-formal (Adawiyah et al., 2017; Hidayat et al., 2017; Kuntoro, 2006; Purnamasari, 2017; Sudiapermana, 2009).

Pusat Kegiatan Belajar Masyarakat (PKBM) merupakan salah satu lembaganon formal yang ada di Indonesia. PKBM adalah lembaga yang dibentuk oleh masyarakat yang bergerak dalam bidang pendidikan. PKBM sebagai suatu wadah berbagai kegiatan pembelajaran masyarakat diarahkan pada pemberdayaan potensi untuk menggerakkan pembangunan di bidang sosial, ekonomi dan budaya (Ariyanti et al., 2017; Finola et al., 2017; Sulfemi, 2019). Program-program yang diselenggarakan di PKBM dapat sangat beragam dan dapat juga tak terbatas, sesuai dengan potensi dan kebutuhan masyarakatnya, serta bermakna dan bermanfaat. Salah satu program dari PKBM adalah Pendidikan Kesetaraan Paket A, Paket B dan Paket C. Paket A setara dengan Sekolah Dasar, Paket B setara dengan Sekolah Menengah Pertama dan Paket C setara dengan Sekolah Menengah Atas (Ekananto, 2014; Handayani, 2017; Rosalina et al., 2015). 
Pendidikan kesetaraan dalam PKBM sangat penting dalam pelaksanaan pendidikan karena perannya dalam menyiapakan Sumber Daya Manusia yang berpendidikan dan berkarakter. Program pendidikan kesetaraan baik Paket A, $\mathrm{B}$, dan $\mathrm{C}$ dapat memberikan pendidikan non formal pada warga masyarakat yang putus sekolah atau belum bersekolah sehingga dapat menghasilkan SDM yang berpindidikan setara SD, SMP maupun SMA (I. K. D. Hermawan, 2012; Nugroho, 2014; Rohmaniah, 2019). Salah satu kegiatan belajar dalam program pendidikan kesetaraan adalah kegiatan belajar mandiri, yaitu kegiatan pembelajaran yang dirancang dan dilaksanakan oleh warga belajar/peserta didik dengan bimbingan tutor/pendidik. Sehingga terbentuklah SDM yang berkarakter mandiri dalam kegiatan belajar mandiri tersebut (Ashari, 2013; Novitasari, 2015; Yustiani et al., 2015).

Dalam pemenuhan kebutuhan pendidikan berkarakter untuk mengembangkan potensi masyarakat secara maksimal, pendidikan keaksaraan bagi warga belajar turut mengalami perkembangan sesuai dengan tuntutan pendidikan dalam masyarakat yang sedang berkembang saat ini. Hal ini mendorong seluruh aspek kehidupan warga belajar dapat berkembang seiring dengan berkembangnya inovasi pendidikan yang didapatkannya dalam kegiatan belajar mengajar dalam dunia pendidikan mereka (Y. Hermawan, 2017; Mahu, 2011; Rosadi, 2017; Sumardi, 2008).

Pelajaran Bahasa Inggris sebagai salah satu mata pelajaran yang diajarkan pada warga belajar menjadi salah satu hal yang sangat penting untuk diperhatikan karena penggunaan bahasa Inggris baik secara aktif maupun pasif sangat diperlukan dalam menghadapi tantangan masa depan, yaitu era globalisasi: WTO, ASEAN community, APEC, CAFTA, kemajuan teknologi informasi, dan Revolusi Industri 4.0. Penggunaan bahasa Inggris dalam kehidupan sehari-hari banyak kita temukan dalam berita surat kabar, Televisi (audio-visual), Manual book pada alat-alat elektronik, smartphone dan lain-lain. Sehingga Bahasa Inggris sebagai bahasa internasional tidak dapat lepas penggunaannya dalam setiap aspek kehidupan kita. Maka dari itu, mata pelajaran Bahasa Inggris sangat diperlukan untuk membekali warga belajar dalam menghadapi kehidupan sosial kemasyarakatannya.

Salah satu strategi pembelajaran invotif yang mendukung kegiatan belajar bahasa Inggris secara mandiri adalah penggunaan aplikasi internet. Banyak aplikasi internet yang tersedia dan dapat digunakan, namun pemilihan aplikasi yang memungkinkan warga belajar dapat belajar secara mandiri sangat diperlukan (Hossain, 2015; Milrad, 1999; Ventura \& Martín-Monje, 2016). Banyak aplikasi ringan yang bisa digunakan siswa dalam proses pembelajaran yaitu membuat kuis soal Latihan,salah satunya adalah AppsGeyser (Jatmiko, 2014). "AppsGeyser adalah sebuah tools online (Web) gratis yang memungkinkan setiap penggunamya untuk megembangkan aplikasi atau game mobile dalam format kustom Android" (Sujanem et al., 2019; Wahyudi et al., 2019). Dengan aplikasi ini kita dapat dengan mudah mendistribusikan konten dari website, blog, dan file-file tertentu yang ingin kita bagikan melalui aplikasi android, sehingga kita dapat membagikan materi-dalam hal ini adalah Bahasa Inggris-melalui aplikasi ini dan warga belajar dapat menggunakannya secara mandiri.

Beberapa publikasi terdahulu menunjukkan bahwa AppsGeyser telah digunakan untuk membantu proses pembelajaran. Pengembangan pembelajaran menggunakan mobile learning yang di dalamnya termasuk penggunaan AppsGeyser telah diterapkan pada pembelajaran biologi (Aripin, 2018). Pada pembelajaran matematika, telah dibyat aplikasi game puzzleyang berisi materi teori bilangan, aljabar, bangun datar dan bangun ruang. Pada game ini terdapat 15 level dan dibuat dari Appsgeyser (Aini et al., 2019). Implementasi Appsgeyser juga telah diajarkan pada guru-guru fisika (Sujanem et al., 2019).

Adapun tujuan penulisan karya nyata ini adalah mendeskripsikan dan menjelaskan penggunaan aplikasi AppsGeyser dalam kegiatan belajar mandiri mata pelajaran bahasa Inggris pendidikan kesetaraan paket C. Uraian difokuskan pada (1) Implementasi Strategi Pembelajaran; (2) Hasil belajar, dan (3) Dampak, Kendala dan solusi Implementasi Strategi Pembelajaran. Kontribusi penulisan karya nyata ini, antara lain: (1) dapat digunakan sebagai salah satu referensi yang dapat diaplikasikan dalam kegiatan belajar mengajar oleh sesama GTK PAUD dan Pendidikan Masyarakat; (2) dapat digunakan sebagai masukan inovasistrategi pembelajaran dengan memanfaatkan teknologi secara positif oleh satuan PAUD dan Pendidikan Masyarakat; (3) dapat digunakan untuk memantau proses belajar warga belajar oleh orang tua dan masyarakat; dan (4) dapat digunakan untuk mengarahkan penggunaan internet sebagai media belajar secara positif oleh pemerintah pusat dan pemerintah daerah terkait dengan kebijakan implementasi PPK.

\section{METODE}

Metode yang digunakan dalam karya nyata ini adalah deskriptif kuantitatif. Populasi yang digunakan adalah seluruh warga belajar pendidikan kesetaraan kejar paket C di PKBM IImu Barokah yang berjumlah 10 warga belajar dari kelas 3. Instrumen yang digunakan dalam memperoleh data berupa pretest dan posttest dengan teknik analisis data persentase. Strategi pembelajaran yang digunakan adalah Kegiatan Belajar Mandiri. Gambar 1 berikut ini merupakan skema konsep strategi pembelajaran proses kegiatan belajar mandiri mata pelajaran Bahasa Inggris Pendidikan Kesetaraan Paket C. 


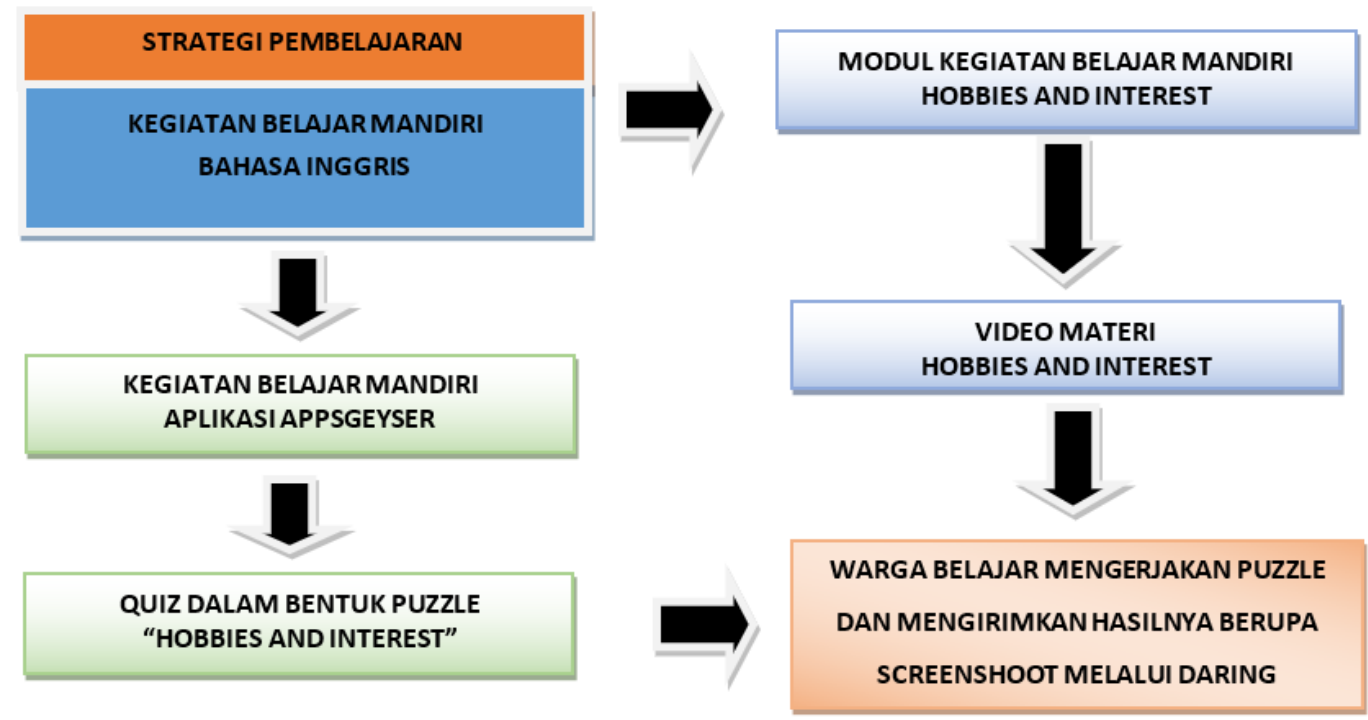

Gambar 1. Skema konsep strategi pembelajaran proses kegiatan belajar mandiri mata pelajaran Bahasa Inggris Pendidikan Kesetaraan Paket C.

Strategi pembelajaran dengan menggunakan kegiatan belajar mandiri diawali dengan memberikan modul materi kegiatan belajar mandiri mata pelajaran Bahasa Inggris kepada warga belajar paket $\mathrm{C}$ dan disertai dengan video materi pembelajaran (materi: Hobbies and Interest). Setelah warga belajar mendapatkan modul yang berisi materi dan video materi pembelajaran, warga belajar dapat memulai menggunakan aplikasi ApssGeyser yang telah terpasang pada perangkat androidnya. Aplikasi ini berupa quiz dalam bentuk puzzle yang berguna untuk mengetahui pemahaman warga belajar terhadap materi yang telah diberikan melalui modul dan video pembelajaran. Quiz dapat dikerjakan berkali-kali sampai warga belajar dapat memahami betul materi "Hobbies and Interest" secara matang. Setelah mengerjakan puzzle tersebut, warga belajar dapat mengirimkan hasil pekerjaannya berupa screenshoot melalui daring kelas atau grub kelas. Dari sini, tutor dapat melihat hasil pekerjaan warga belajar.

Keberhasilan program ini diukur dalam bentuk terimplementasinya aplikasi dalam strategi pembelajaran, adanya peningkatan hasil belajar para warga belajar, dan terdatanya dampak, kendala, dan solusi.

\section{HASIL DAN PEMBAHASAN}

\section{Implementasi Strategi Pembelajaran}

Implementasi strategi pembelajaran dengan menggunakan kegiatan belajar mandiri di awali dengan memberikan modul berupa materi kegiatan belajar mandiri mata pelajaran Bahasa Inggris (Hobbies and Interest) kepada warga belajar paket $\mathrm{C}$ dan disertai dengan video materi pembelajaran (materi: Hobbies and Interest). Setelah warga belajar mendapatkan modul yang berisi materi dan video materi pembelajaran, warga belajar dapat memulai menggunakan aplikasi apssgeyser yang telah terpasang pada perangkat androidnya.

AppsGeyser adalah layanan berbasis online (Web) yang memungkinkan para pengguna membuat Aplikasi Android mereka dari konten sebuah website, atau disebut juga launcher. Dengan AppsGeyser kita dapat dengan mudah mendistribusikan konten dari Website, Blog dan file-file tertentu yang ingin kita bagikan melalui Aplikasi Android. Platform pembuatan aplikasi android AppsGeyser hanya memerlukan waktu beberapa menit saja, sehingga tidak memerlukan waktu yang lama untuk mengaplikasikannya.

Aplikasi ini berupa quiz dalam bentuk puzzle yang dapart dikerjakan secara mandiri dan berguna untuk mengetahui pemahaman warga belajar terhadap materi yang telah diberikan baik melalui modul maupun video materi pembelajaran yang telah diberikan. Quiz dapat dikerjakan berkali-kali sampai warga belajar dapat memahami betul materi "Hobbies and Interest" secara matang. Setelah mengerjakan puzzle tersebut, warga belajar dapat mengirimkan hasil pekerjaannya berupa screenshoot melalui daring kelas atau grub kelas. Dari sini, tutor dapat melihat hasil pekerjaan warga belajar.

Langkah-langkah untuk membuat aplikasi AppsGeyser, yaitu (1) Buka situs http://www.AppsGeyser.com/ (Gambar 2); (2) Masukkan alamat E-mail dan Password yang pernah didaftarkan pada appgeyser atau login melalui akun Facebook; (3) Setelah aplikasi terbuka, klik CREATE APP, maka akan tampil layout; (4) Untuk membuat kuis, klik GAME pilih PUZZLE lalu klik; (5) Pilih QUIZ, lalu klik; (6) Isi pertanyaan pada kolom Questions, masukkan gambar pada Attach Image serta masukkan option jawaban pada kolom Answers. Jangan lupa memilih jawaban yang benar pada pilihan Correct answer is; (7) Untuk menambah soal, klik Add question; (8) Kuis akan menampilkan 10 soal (default) yang 
kita buat secara acak, baik soal maupun option jawabannya. Misalnya kita memasukkan 40 soal, maka akan dipilih secara acak 10 soal untuk ditampilkan. Untuk mengubah jumlah soal yang akan ditampilkan ubah kolom Questions per one game sesuai yang diinginkan; (9) Setelah seluruh soal dibuat, berikutnya kita buat judul APP, misalnya pada kuis ini saya beri judul Introduction; (10) Buat diskripsi singkat pada kolom Description; (11) Masukkan latar belakang pada aplikasi yang kita buat dengan memasukkan gambar melalui Upload background image; (12) Langkah terakhir adalah klik CREATE APP, maka akan tampil APP hasil karya kita, untuk melihat hasilnya klik Preview (Gambar 3); (13) Maka akan tampil preview APP hasil karya yang dibuat (Gambar 4); (14) Setelah preview sesuai yang diinginkan, download aplikasi yang sudah jadi melalui menu DOWNLOAD; dan (15) File yang sudah didownload (berextensi .apk) dapat langsung dimasukkan ke HP Android dan install lalu jalankan. Aplikasi akan berjalan sesuai preview yang ditampilkan.

Q. Mudah Membuat Aplikasi And $\mathrm{X}$

$\leftarrow \rightarrow$ C
Sign In FREE App Creator. Crea $\times+$

(i) 을 https://www.appsgeyser.com/login/?returl=\%2Fdashboard\%2F

\section{REGISTER/SIGN IN}

\begin{tabular}{|l|l|}
\hline Register & Sign In \\
\hline G & Sign in with Google \\
\hline f & Sign in with Facebook \\
\hline
\end{tabular}

Sign in with E-mail

By signing up you agree to Appsgeyser's

Terms of Service and Privacy Policy.

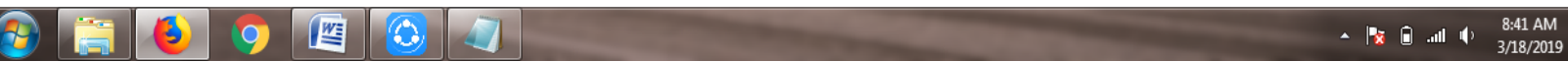

Gambar 2. Tampilan situs http://www.AppsGeyser.com/

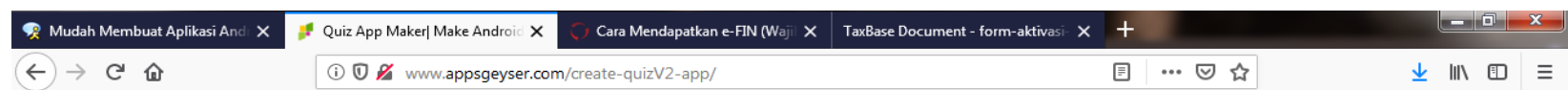

\section{CREATE QUIZ V.2.0 APP}

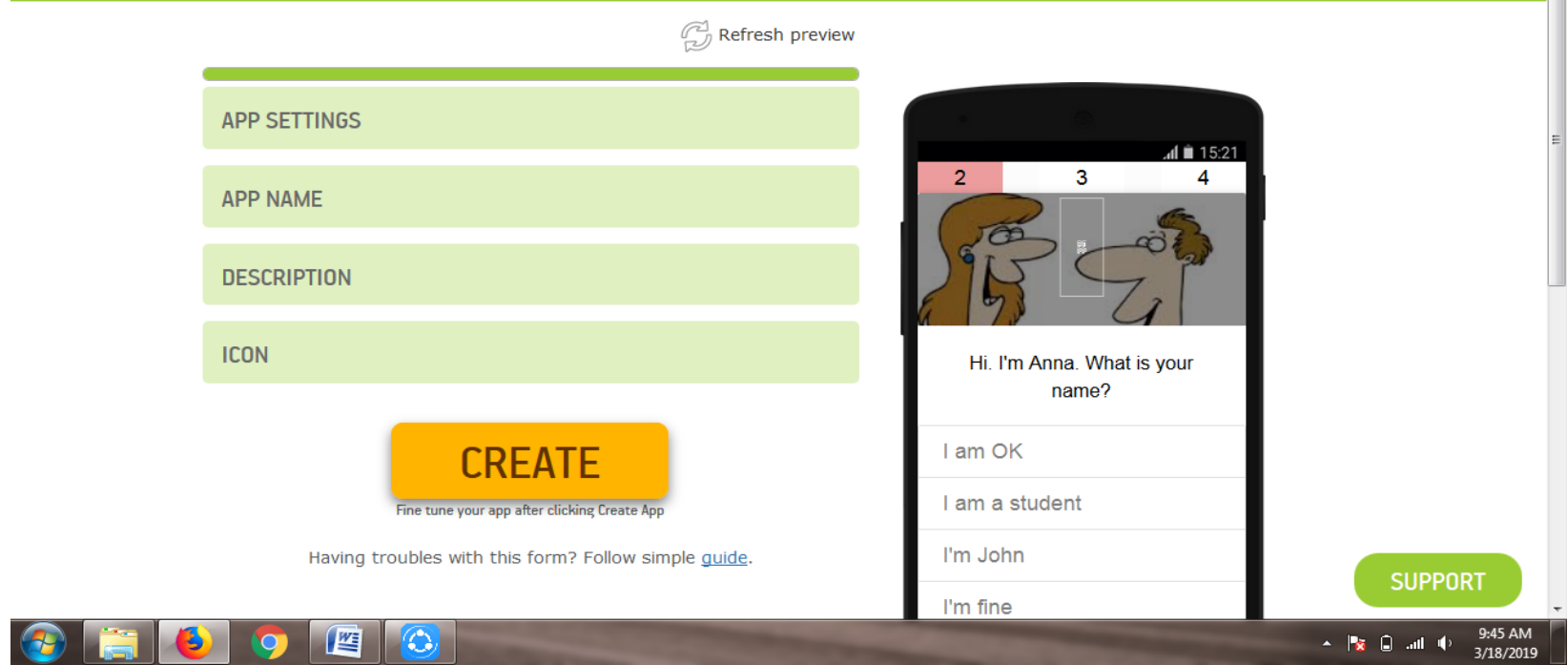

Gambar 3. Tampilan ketika klik Preview 


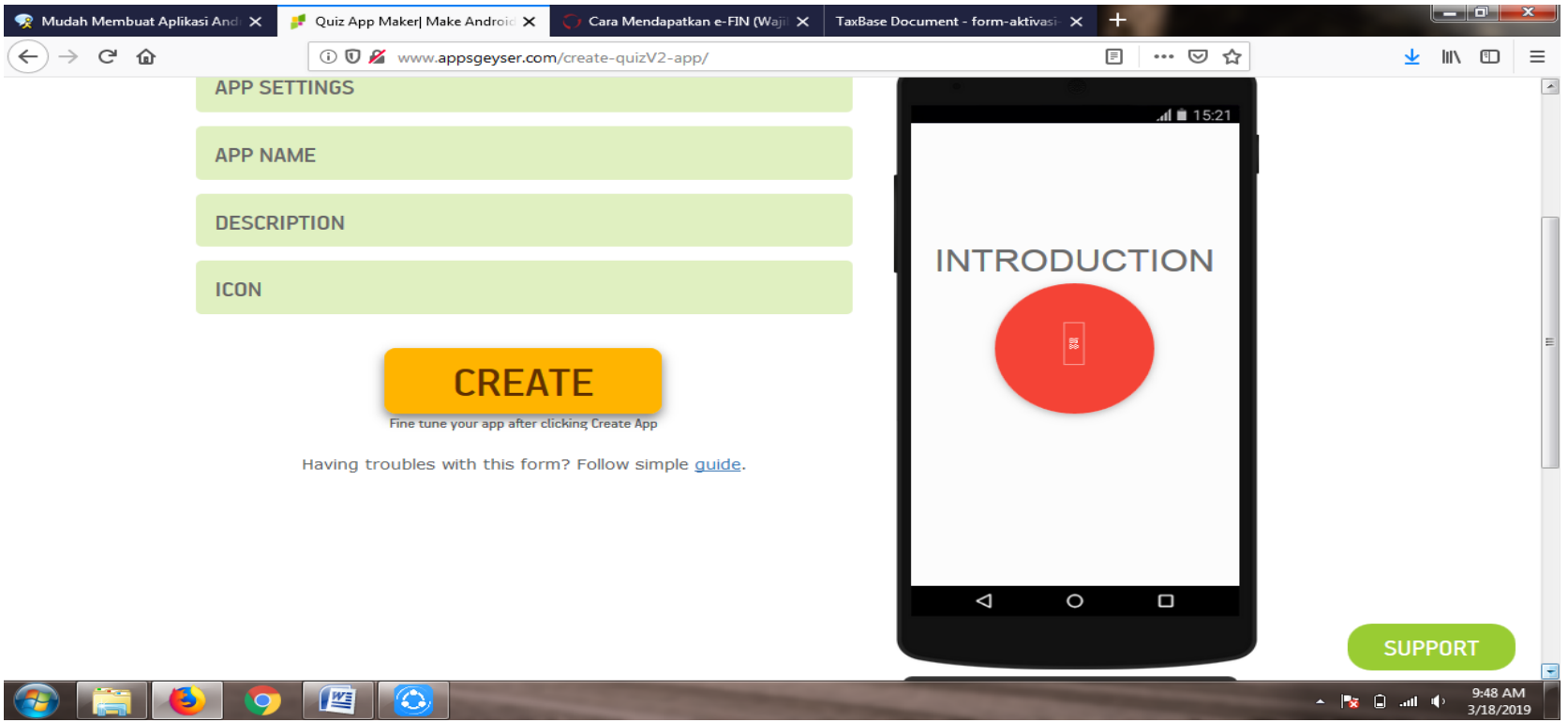

Gambar 4. Tampilan preview APP hasil karya yang dibuat

Penggunaan android dalam proses kegiatan pembelajaran Bahasa Inggris secara mandiri ditujukan agar warga belajar dapat menggunakan media ini sebagai sarana belajar secara mandiri karena aplikasi untuk mendukung kegiatan belajar mandiri dapat dijalankan melalui android yang dapat dibawa kemana-mana dan dapat dilakukan dimana saja. Warga belajar akan dapat belajar dengan mandiri. Selain itu, penggunaan Bahasa Inggris dalam sistem smartphone android dapat mendukung proses belajar warga belajar dalam mata pelajaran ini.

\section{Hasil belajar}

Adapun hasil yang dicapai warga belajar setelah menggunakan aplikasi AppsGeyser sebagai media belajar yaitu: warga belajar menjadi lebih mudah dalam mengerjakan kuis karena dapat dikerjakan melalui smartphone mereka. Warga belajar juga dapat mengerjakan kapanpun dan dimanapun, mengingat latar belakang kehidupan sosial dan lingkungan warga belajar yang berbeda-beda (ada yang bekerja dan ada yang menganggur). Warga belajar lebih bersemangat dalam mengerjakan kuis secara mandiri karena model asessmen yang dibuat seperti bermain game, jadi lebih menyenangkan dan tidak membosankan. Selain itu warga belajar lebih mudah mengingat materi sehingga dapat menjawab kuis dengan lancar karena mengerjakan kuis secara online dan mirip seperti bermain game pada smartphone. Warga belajar semakin mandiri dalam mempelajari materi pembelajaran karena dapat diimplementasikan secara mandiri oleh warga belajar. Hasil evaluasi warga belajar meningkat dibandingkan ketika belum menggunakan aplikasi dalam kegiatan belajar mandiri. Daftar kenaikan nilai warga belajar sebelum dan sesudah menggunakan aplikasi ada di Tabel 1.

Tabel 1. Daftar nilai bahasa Inggris warga belajar sebelum dan sesudah menggunakan aplikasi AppsGeyser

\begin{tabular}{cccc}
\hline No. & Nama Warga Belajar & Sebelum Menggunakan Aplikasi & Sesudah Menggunakan Aplikasi \\
\hline 1 & FK & 65 & 85 \\
2 & RI & 60 & 85 \\
3 & MAM & 75 & 90 \\
4 & DP & 60 & 85 \\
5 & BF & 65 & 80 \\
6 & CD & 65 & 85 \\
7 & RC & 60 & 85 \\
8 & SL & 75 & 90 \\
9 & VN & 60 & 85 \\
10 & SK & 65 & 80 \\
\hline
\end{tabular}

Berdasarkan Tabel 1 ada kenaikan nilai warga belajar sebelum dan sesudah menggunakan aplikasi ApssGeyser dalam mengerjakan kuis. Nilai warga belajar meningkat antara 20-30\%. Hal ini sejalan dengan Aripin (2018) bahwa penggunaan internet sebagai sarana belajar-dalam hal ini adalah penggunaan ApssGeyser-telah memberikan peran yang lebih besar pada guru sebagai fasilitator dan motivator pembelajaran. Menurut Aini et al (2019), dampak dari penggunaan aplikasi ApssGeyser ini adalah media pembelajaran berpengaruh pada kemampuan berpikir pengguna (peserta didik/warga belajar). Menurut Sujanem et al (2019), penggunaan ApssGeyser membant mengoptimalkan kualitas pembelajaran yang dilaksanakan. 


\section{Dampak, kendala dan solusi implementasi strategi pembelajaran}

Dampak implementasi penggunaan aplikasi ApssGeyser terhadap prestasi warga belajar menunjukkan bahwa warga belajar mengalami peningkatan dalam hasil evaluasi. Sikap warga belajar juga menjadi lebih aktif dan bersemangat dalam mengerjakan kuis mata pelajaran bahasa inggris yang dianggap sulit dan menakutkan. Warga belajar secara mandiri dan bertanggung jawab dapat mengerjakan kuis atau penilaian yang diberikan. Hal ini menunjukkan bahwa adanya peningkatan dalam karakter warga belajar. Selain itu warga belajar menjadi lebiha aktif dan bersemangat dalam mengikuti kelas daring online (pembelajaran tidak langsung) dan non-online (pembelajaran langsung) karena selalu ada hal baru yang dapat dipelajari. Sehingga kegiatan belajar mengajar lebih bermakna dan menyenangkan bagi warga belajar dan tutor pengajar.

Kendala yang muncul dalam penerapan strategi ini adalah tidak semua warga belajar memiliki smartphone sehingga proses kegiatan belajar mandiri belum dapat berjalan secara maksimal. Warga belajar yang belum memiliki smartphone belum dapat menggunakan aplikasi ini untuk belajar dan mengerjakan quiz. Adapun solusi untuk kendala ini adalah warga belajar yang belum memiliki smartphone dapat menggunakan smartphone saudara atau walinya. Selain itu warga belajar juga dapat menggunakan perangkat komputer yang telah di install aplikasi AppsGeyser.

PKBM memberikan dukungan dengan menyediakan wifi untuk warga belajar untuk mengunduh aplikasi secara online ketika kegiatan belajar mengajar. Sarana prasarana pendukung penggunaan aplikasi ini telah dimiliki oleh warga belajar dan tutor pengajar karena hanya memerlukan smartphone bagi warga belajar dan lap top atau computer bagi tutor pengajar. Masyarakat dalam hal ini wali dari warga belajar memberikan dukungan secara moral dengan memberikan pantauan pada warga belajar dalam memanfaatkan aplikasi ini.

Masyarakat saat ini telah memiliki media smartphole yang semestinya dapat dimanfaatkan dalam pembelajaran, namun hanya dipergunakan sebabatas untuk bermain media sosial, selfie, dan main game (Sujanem et al., 2019). Alangkah baiknya jika game yang dibuat dan dimainkan oleh peserta didik adalah game yang dimanfaatkan di dunia pendidikan guna mendukung kegiatan belajar mengajar dan menarik minat motivasi belajar mereka (Aini et al., 2019). Untuk membantu proses pembelajaran, saat ini sudah banyak pilihan yang dapat digunakan. Menurut Nurohman (2013), cukup mudah caranya, yaitu "kunjungi situs http://www.appsgeyser.com/, kemudian ikuti langkah-langkah pendaftaran yang tersedia. Jika seluruh langkah sudah dijalankan, maka aplikasi web launcher untuk web pembelajaran yang sudah dibangun sebelumnya dapat dipasang pada smartphone berplatform Android".

Kami merencanakan untuk mengembangkan strategi ini dengan membaginya bersama tutor pengajar mata pelajaran yang lain. Sehingga tidak hanya digunakan dalam mata pelajaran bahasa inggris saja, namun dapat digunakan oleh tutor pengajar mata pelajaran yang lain. Selain itu penulis berharap hasil karya nyata ini dapat dimanfaatkan bagi tutor pengajar atau guru sekolah formal yang lain.

\section{KESIMPULAN}

Berdasarkan hasil dan pembahasan dapat disimpulkan bahwa penggunaan AppsGeyser dalam kegiatan belajar mandiri pendidikan kesetaraan paket $\mathrm{C}$ sangat membantu warga belajar untuk meningkatkan hasil capaian belajar dan membuat mereka lebih tertarik untuk belajar. Saran yang dapat diberikan oleh penulis antara lain adalah sebagai berikut Bagi pengelola PKBM, hendaknya menyediakan fasilitas (sarana dan prasarana) yang memadai dan sesuai untuk mendukung kegiatan belajar mengajar. Selain itu hasil penelitian ini bagi tutor Kejar Paket yang lain dapat dijadikan acuan dalam merefleksikan diri mereka untuk meningkatkan kompetensi maupun kualifikasi keilmuan mereka. Bagi warga belajar, hasil penelitian karya nyata ini dapat dijadikan bahan pengembangan diri untuk meningkatkan semangat dan minat belajar mereka. Rekomendasi ini dapat dijadikan sebagai bahan pertimbangan dalam melakukan pembinaan terhadap PKBM diwilayah kerjanya khususnya pembinaan bagi tutor PKBM serta sebagai pertimbangan untuk perencanaan program pembinaan selanjutnya.

\section{UCAPAN TERIMA KASIH}

Terima kasih kami sampaikan kepada pimpinan dan tim Pusat Kegiatan Belajar Masyarakat (PKBM) IImu Barokah Blitar Jawa Timur yang telah mendukung kegiatan ini, baik secara moril maupun materiil.

\section{REFERENSI}

Adawiyah, A., Sulfasyah, S., \& Arifin, J. (2017). Implikasi Pendidikan Nonformal Pada Remaja. Equilibrium: Jurnal Pendidikan, 4(2), 1-8. https://doi.org/10.26618/equilibrium.v4i2.506

Aini, B. O., Ayu, K. C., \& Siswati, S. (2019). Pengembangan Game Puzzle Sebagai Edugame Berbasis Android Untuk Meningkatkan Kemampuan Berpikir Matematika Siswa SD. JTAM / Jurnal Teori Dan Aplikasi Matematika, 3(1), 74. https://doi.org/10.31764/jtam.v3i1.768

Aripin, I. (2018). Konsep Dan Aplikasi Mobile Learning Dalam Pembelajaran Biologi. Jurnal Bio Educatio, 3(1), 1-9.

Ariyanti, S., Pendidikan, J., Islam, A., Tarbiyah, F., \& IImu, D. A. N. (2017). Peran Pusat Kegiatan Belajar Masyarakat 
(PKBM) Dalam Membina Masyarakat Putus Sekolah (Studi Kasus Pkbm Bustanul Muslimin Desa Genting Kecamatan Jambu Kabupaten Semarang) Tahun 2017. IAIN Salatiga.

Ashari, D. (2013). Model Pembelajaran Warga Belajar Kejar Paket C Di Tinjau Dari Prestasi Belajar Di Sanggar Kegiatan Belajar Gunungpati Kota Semarang. Universitas Negeri Semarang.

Chakraborty, S., Chakraborty, B., Dahiya, V. S., \& Timajo, L. (2018). Education as an instrument of social change and enhancing teaching-learning process with the help of technological development. ResearchGate, May, 0-16.

Ekananto, S. (2014). Analisis kebutuhan pengembangan pusat kegiatan belajar masyarakat (PKBM) Tunas Muda Desa Cacaban Kidul, Kecamatan Bener, Kabupaten Purworejo. Universitas Negeri Yogyakarta.

Finola, O., Irja, D., \& Maemunaty, T. (2017). The Study of Organization PKBM (Pusat Kegiatan Belajar Masyarakat) in the City Dumai. JOMFKIP, 4(1), 1-10. https://jom.unri.ac.id/index.php/JOMFKIP/article/view/13365

Gartman, D. (2002). Bourdieu's Theory of Cultural Change: Explication, Application, Critique. Sociological Theory, 20(2), 255-277. http://www.jstor.org/stable/3108649

Gusnimar, G., \& Siahaan, D. N. A. (2018). Implementasi program pembelajaran PAI dan pembentukan kepribadian muslim sejati. ITTIHAD, 2(1), 29-42.

Handayani, R. (2017). Pengelolaan Program Pendidikan Kesetaraan Kejar Paket C Di Pusat Kegiatan Belajar Masyarakat (PKBM) Citra Ilmu. Universitas Negeri Semarang.

Hermawan, I. K. D. (2012). Kinerja pendidikan kesetaraan sebagai salah satu jenis pendidikan nonformal. Jurnal Pendidikan Dan Kebudayaan, 18(September 2011), 65-84.

Hermawan, Y. (2017). Keaksaraan Berbasis Potensi Lokal dalam Upaya Pemberdayaan Masyarakat Desa. Jurnal AKRAB, 37-39.

Hidayat, M. A., Anwar, A., \& Hidayah, N. (2017). Pendidikan Non Formal Dalam Meningkatkan Keterampilan Anak Jalanan. Edudeena, 1(1), 31-42. https://doi.org/10.30762/ed.v1i1.445

Hossain, M. I. (2015). Teaching Productive Skills to the Students: A Secondary Level Scenario. BRAC University.

Jatmiko, T. (2014). Membuat kuis untuk pembelajaran mengunakan aplikasi Android-Step by Step. Guraru.Com. https://guraru.org/guru-berbagi/membuat-kuis-untuk-aplikasi-android-step-by-step/

Kuntoro, S. A. (2006). Pendidikan Nonformal (PNF) Bagi Pengembangan Sosial. Jurnal IImiah VISI PTK-PNF, 1(2), 14-18. https://core.ac.uk/download/pdf/295555318.pdf

Mahu, S. (2011). Pengembangan Model Pembelajaran Keaksaraan Fungsional Berbasis Potensi Pertanian Bagi Pemberdayaan Komunitas Adat Terpencil. Jurnal IImiah VISI PPTK-PAUDNI, 6(1), 20-29. https://doi.org/10.21009/jiv.0601.3

Milrad, M. (1999). Designing an Interactive Learning Environment to Support Children 's Understanding in Complex Domains Designing an Interactive Learning Environment to Support Children's Understanding of Complexity. Thinking, September, 1-178.

Novitasari, D. (2015). Penyelenggaraan Pendidikan Kesetaraan Paket C di Unit pelaksana teknis Sanggar Kegiatan Belajar Kabupaten Gunungkidul (Issue April). Universitas Negeri Yogyakarta.

Nugroho, A. A. (2014). Dinamika implementasi kebijakan pendidikan kesetaraan kejar paket C di PKBM Maju Mundur. Universitas Negeri Yogyakarta.

Nurohman, S. (2013). Pengembangan aplikasi physics mobile learning pada gadget berplatform android guna meningkatkan akses belajar fisika di era global (Issue November).

Pratiwi, E. Y. R. (2018). Upaya Meningkatkan Kesadaran Sejarah Nasional Di Era Globalisasi. Civic Edu: Jurnal Pendidikan Kewarganegaraan, 2(1), 1-11.

Pruneri, F., \& Bianchi, A. (2010). School reforms and university transformations and their function in Italy from the eighteenth to the nineteenth centuries. History of Education, 39(1), 115-136. https://doi.org/10.1080/00467600903464892

Purnamasari, I. (2017). Homeschooling dalam Potret Politik Pendidikan: Studi Etnografi pada Pelaku Homeschooling di Yogyakarta. Journal of Nonformal Education, 3(1), 28-39.

Rohmaniah, S. (2019). Upaya peningkatan minat belajar anak putus sekolah melalui pendidikan akhlaq (kejar paket) pada komunitas belajar Qaryah Thayyibah (QT) tahun 2019 [IAIN Salatiga]. https://core.ac.uk/download/pdf/295326217.pdf

Rosadi, A. (2017). Dampak pendidikan keaksaraan fungsional terhadap peningkatan kualitas hidup sosial ekonomi di Desa Parado Wane Kecamatan Parado Kabupaten Bima. Muamalat Jurnal Hukum Ekonomi Syariah, 9(2), 130-159.

Rosalina, V., Dwiyatno, S., \& Harsiti, H. (2015). Perancangan Infrastruktur Jaringan Komputer E-Learning Pada Pusat Kegiatan Belajar Masyarakat (PKBM) di Kota Serang. Jurnal PROSISKO, 2(1).

Sandi, A. (2018). Upaya meningkatkan hasil belajar matematika siswa pada pokok bahasan aljabar melalui pembelajaran kooperatif tipe student teams achievement division (STAD) dengan penedekatan pemecahan masalah dikelas VIII MTS Zia Salsabila Bandar Setia. Seminar Nasional Matematika Dan Terapan, 61-68.

Sarima, A., Jusma, J., \& Ramlah, R. (2020). Analisis Kebijakan Full Day School Dalam Membentuk Karakter Siswa. MAPPESONA : International Jurnal of Educational Management, 2(1), 1-12. https://jurnal.iain- 
bone.ac.id/index.php/mappesona/article/view/778\#

Sudiapermana, E. (2009). Pendidikan Informal: Reposisi, Pengakuan, dan penghargaan. Jurnal Pendidikan Luar Sekolah, $4(2), 1-7$.

Sujanem, R., Suswandi, I., \& Yasa, P. (2019). Pelatihan dan pendampingan pembuatan media pembelajaran fisika berbasis android bagi guru-guru fisika SMA di Kuta.

Sulfemi, W. B. (2019). Modul Manajemen Pendidikan Non Formal. STKIP Muhammadiyah Bogor. https://doi.org/10.31227/osf.io/p9bez

Sumardi, K. (2008). Model Pembelajaran Keaksaraan Dasar Menggunakan Kombinasi Metode Reflect, Lea, Dan Pra. Jurnal IImiah VISI PTK-PNF, 3(2), 107-119. https://doi.org/10.21009/jiv.0302.1

Tusyana, E. (2019). Pengaruh model pembelajaran tipe practice rehearsal pairs terhadap hasil belajar fiqih kelas $3 \mathrm{MI}$ Ismaria Al- Qur'aniyyah Rajabasa Bandar Lampung. Terampil Jurnal Pendidikan Dan Pembelajaran Dasar, 6(1), 2333.

Ventura, P., \& Martín-Monje, E. (2016). Learning specialised vocabulary through Facebook in a massive open online course. In New perspectives on teaching and working with languages in the digital era. https://doi.org/10.14705/rpnet.2016.tislid2014.427

Wahyudi, M. A., Anardani, S., \& Hapsari, E. D. (2019). Pengembangan Aplikasi Multimedia Pembelajaran Penulisan Daftar Pustaka Karya Ilmiah Berbasis Android Menggunakan Appsgeyser. Prosiding Seminar Nasional Teknologi Informasi Dan Komunikasi (SENATIK), 2(1), 23-30.

Yustiani, G., Abdulhak, I., \& Pramudia, J. R. (2015). Peran Tutor untuk Meningkatkan Motivasi Belajar Peserta Didik dalam Pembelajaran Mandiri (Studi Pada Program Pendidikan Kesetaraan Paket C di PKBM Geger Sunten Lembang). Jurnal Pendidikan Non Formal Dan Informal, 7(2), 1-17.

http://ejournal.upi.edu/index.php/PNFI/article/download/5588/3794 